DOI: 10.35218/armca.2021.1.03

\title{
The iconographical diversity of the Sirens' physical forms in medieval bestiaries
}

\author{
Juliana Santos Dinoá Medeiros*
}

\begin{abstract}
This article analyses the physical representation's forms of the Siren in medieval bestiaries. Depending on the manuscript, the creature could appear in three hybrid forms: bird-woman, fish-woman and fish-bird-woman. The difference draws attention, considering that the text is the same in each manuscript and specifies the Siren's physical as being that of a bird-woman. Starting from a reconstruction of the Siren myth, since its origin to the Middle Ages, we see how the beast was transformed from a bird-woman into a fishwoman and how this very transformation was received in the bestiaries. Considering the particular relation between image and text in bestiaries and conceiving them as independent traditions, we realize that, contrary to previous studies, the distinct representations were not the result of confusion among different creatures. It is the illuminator who associates the textual description (that determined the Siren asa bird-woman) with his contemporary imagery (that consolidated the Siren as a fish-woman).
\end{abstract}

Keywords: Siren, medieval bestiary, iconography, fantastic creature, hybrids, art history

\section{Introduction}

The Siren is one of several beasts that compose medieval bestiaries. Far from being a treatise on medieval zoology, the bestiary genre represented beasts (real or fantastic animals) and moralised them, attributing to them positive or negative allegories related to Christian doctrine. The bestiary manuscripts have a remarkably similar structure, with a chapter composed of text and illustration for each beast. In addition to their structures, all bestiaries have, in general, similar text and iconographic programme ${ }^{1}$. Due to their elaboration process, bestiaries typically have texts that contain the same idea of moralisation for each animal and mention equal literary sources. On

\footnotetext{
* Master's Student at the Faculty of Letters, University of Lisbon, Lisbon; e-mail: juliana.652@gmail.com

${ }^{1}$ This similarity was amply analysed by Florence McCulloch. She schemed a division into families according to bestiaries' common characteristics (see McCulloch, Florence, Mediaeval Latin and French bestiaries, University of North Carolina Press, Chapel Hill, 1962).
} 
the other hand, illustrations have a greater degree of singularity, although they also represent situations and descriptions present in the text.

TheSiren's physical form as it appears represented in the illustrations varies according to the analysed manuscript. Altogether, it can take three forms. In the first form, the Siren is a hybrid of a woman and a bird, with a female head and torso, and the bottom of a bird, with wings and claws. In the second one, it preserves the upper human half, but the lower half is pisciform, with tail and scales. Finally, in the third, the creature is a mixture of the first two forms: a woman with a scaly tail, wings and claws.

Despite the various research on the Siren's iconographical representation throughout history, few were directed to their presence in bestiaries. Namely, two authors elaborated a reflection on the issue: Florence McCulloch and Michel Pastoureau. McCulloch determined that the way the beasts were illustrated depended on the illuminator's interpretation of the text during the manuscript's production ${ }^{2}$. According to her, the elements and, consequently, the physical way the animals were illustrated were subjective. However, they would still maintain an association with what was directly or indirectly present in the text. As for Pastoureau, he argued that the Siren-bird and the Siren-fish were distinct beasts, the first being equated with harpies. Additionally, he also stated that the Sirens' representation as a mixed fishbird would be an illuminator's confusion between these first two distinct types of Sirens ${ }^{3}$. Nevertheless, the two authors did not consider the complex association that texts and images have in bestiaries, as McCulloch overestimated only the textual influence, while Pastoureau underestimated it.

Therefore, seeking to fill this theoretical gap, this paper intends to reinterpret these different ways of representation, by considering the relation between image and text in bestiaries, as well asby assuming them as independent traditions and carriers of their unique logic. Initially, through the reconstruction of the Siren myth since its origin in Antiquity until the 12th century(the most significant period for bestiaries' production) we will draw attention mainly to how the forms of physical representations of the Siren have evolved. Secondly, we will relate the textual description of the Siren's appearance in the bestiaries with what was illustrated in specific manuscripts. In this way, we will analyse the level of textual influence on each manuscript's illustrations, avoiding generalisations. Lastly, we will propose our reflection on what determines the physical shape of the Sirens in the bestiaries' images, confronting the arguments of McCulloch and Pastoureau at the same time.

\footnotetext{
${ }^{2}$ Ibid., p. 71.

${ }^{3}$ Pastoureau, Michel, Bestiaires du Moyen Âge, Seuil, Paris, 2011, pp. 189-190.
} 


\section{From the myth's origins to the Middle Ages}

The Siren's first mention in literature occurs in Homer's poemOdyssey, written around the $7^{\text {th }}$ century BC. Hence, the book XII narrates, in particular, the challenges that Ulysses had to face and the sea monsters that he had to fight. In the tale, Ulysses is warned by the goddess Circe about the Sirens, creatures that seduce sailors with their beautiful songs and make them swim to their island, where they would $\mathrm{die}^{4}$. Although deadly, the Siren's singing would bring great wisdom to those who would hear it. Therefore, Ulysses ordered his sailors to cover his ears with wax and tie him to the mast of the ship, under the order not to let him loose. Once safe, the hero received valuable advice from the Sirens and went on his journey. Despite offering essential characteristics of the Siren's behaviour, the Odyssey does not describe them physically; it only determines that two creatures tempted Odysseus.

The Siren's physical characterisation and its iconographical construction occurred after the Odyssey tale, between the $7^{\text {th }}$ and $6^{\text {th }}$ centuries $\mathrm{BC}$, when it started to be identified as a hybrid being, with the body of a bird and human head, not always a female one ${ }^{5}$. According to Rodríguez-López, this description was influenced by images of hybrid beings from Eastern cultures, particularly Egyptian, who arrived in Greece during the "orientalisation" of the $7^{\text {th }}$ century $\mathrm{BC}^{6}$. In Egyptian culture, the bird-human creature was present mainly in funerary contexts, representing the soul of the deceased $^{7}$. However, when incorporated into Hellenistic culture, the hybrid was associated with the Siren's identity and itwas, from the 6th century BC., represented together with Ulysses ${ }^{8}$. From that same century, Sirens acquired a human torso intending to give them arms that held musical instruments 9 Usually, they started to be represented in a trio, in which one sang, and the other two had a lyre and an aulos ${ }^{10}$.

Sirens genealogy is a matter of discussion. Some literary sources defined them as daughters of the river god Achelous and Sterope, while others, more often, of Achelous and one of the Muses (Terpsichore,

\footnotetext{
${ }^{4}$ While the original story does not give the reader the reason sailors would find death, some late authors relate it to the lack of food or water: intoxicated by music, sailors would forget to eat and drink (Leclercq-Marx, Jacqueline, La Sirènedans la penséeetdansl'art de l'Antiquité du Moyen Âge, 02/10/2014, koregos.org).

${ }^{5}$ Holford-Strevens, Sirens in Antiquity and the Middle Ages, inMusic of the Sirens, Indiana University Press, Bloomington, 2006, 16-51, p. 17.

${ }^{6}$ Rodríguez López, op. Cit., p. 339.

${ }^{7}$ Ibidem.

${ }^{8}$ Leclercq-Marx, op. Cit.

${ }^{9}$ Holford-Strevens, op. Cit., p. 18.

${ }^{10}$ Rodríguez López, op. Cit., p. 342.
} 
Melpomene or Calliope ${ }^{11}$; on the other hand, some claimed that they were born of the blood of Achelous when he was wounded by Heracles ${ }^{12}$. In Greek mythology, the Sirens were initially companions of Persephone. After Hades, the god of the underworld, abducted Persephone, the Sirens became birdwomen, either of their own accord or because of Demeter's punishment for not having saved her daughter ${ }^{13}$.

Written sources throughout Antiquity also perpetuated the physical interpretation of the Sirens as bird-women. For example, they were, according to Apollonius, shaped partly as birds and partly as damsels ${ }^{14}$; to Ovid, they had bird's clawsand a maiden's face ${ }^{15}$; to Hyginus, they had the upper part of a woman and the lower part of a bird ${ }^{16}$.

In short, the Siren's identification as a hybrid of a woman and a bird was prevalent in written sources and was the first form of the creature's iconic representation. However, it was not the only one. Exclusively in the images, the bird-woman Siren coexisted with a fish-woman figure; that is, the Siren appeared with a woman's trunk and a fishtail. Until 1962, the first appearance of the pisciform Siren was dated to the $2^{\text {nd }}$ century, when it was found figured in Roman lamps ${ }^{17}$. There, two Sirens surrounded the ship of Ulysses and two other sailors, portraying the passage of the Odyssey in which the hero is tied to the mast to listen to the sweet song of the creatures ${ }^{18}$. However, in that same year, Odette Touchefeu-Meynier demonstrated, based on a newly discovered Megarian bowl, that the appearance was much later than imagined, dating back to the $3^{\text {rd }}$ century $\mathrm{BC}^{19}$. Art historians interpreted this transformation from the bird-woman to the fish-woman as a confusion between Siren and Scylla, another sea monster that Ulysses faces on his journey $^{20}$.

As mentioned before, this reinterpretation of the Siren's physique happened only in visual arts, since it would only be in the $7^{\text {th }}$ century,

\footnotetext{
${ }^{11}$ Holford-Strevens, op. Cit., p. 19. Accordingto Pérez Suescunand Rodríguez López, themusicalityandseductionoftheSirens' songderived "precisely" fromtheircondition as daughtersof a Muse (Pérez Suescun, Fernando; López, Maria Victoria Rodríguez, Las Sirenas medievales: aproximación literária e iconográfica, in Anales de Historia del Arte $\mathrm{n}^{\mathrm{o}} 7$, ServicioPublicacionesUCM, Madrid, 1997, 55-66, p. 55).

12 Rodríguez López, María Isabel, La música de las Sirenas, in Cuadernos de Arte e Iconografía, $n^{o} 32$, FundaciónUniversitariaEspañola, Madrid, 2007, 333-357, p. 334.

${ }^{13}$ Pérez Suescun;López, op. Cit., p. 56.

${ }^{14}$ Ibidem.

${ }^{15}$ Ibidem.

${ }^{16}$ Faral, Edmund, La queue de poisson des sirènes, in Romania, no 296, 1953, pp. 433-506, p. 440.

${ }^{17}$ Touchefeu-Meynier, Odette, De quand date la Sirène-poisson ?, in Bulletin de l'Association Guillaume Budé: Lettres d'humanité, n²1, 1962, 452-459, p. 453.

${ }^{18}$ Ibidem.

${ }^{19}$ Ibid., p. 455.

${ }^{20}$ Leclercq-Marx, op. Cit.
} 
in Liber Monstruorum, that the first textual description of the Siren as a pisciform being would appear ${ }^{21}$. In this book, the Sirens were described as having from the head to the belly a female body, but with a scaly fishtail, with which it swims in depths ${ }^{22}$. We believe that the reason for this late appearance in written sources is due to the greater rigidity of the textual tradition, which, through successive processes of copying texts and consulting previous works, managed to preserve the appearance of the Siren as a bird-woman.

In fact, the imagery is more fluid and susceptible to reinterpretations, in such a way that, already in the Middle Ages, other forms of the Siren's iconography were identified ${ }^{23}$. In contrast, while the bird-woman reigned as primary identity in Antiquity, the fish-woman appeared in the most defined form of the Siren in the Middle Ages, especially in architectural decoration ${ }^{24}$. More interesting are the fishtail's forms in the Romanesque style, which became bifid mainly from the $12^{\text {th }}$ century onward, with a notable recurrence in the Iberian Peninsula ${ }^{25}$.

However, while the novelty of the Siren's iconographical form as a pisciform creature does not alter its symbology, the Advent of Christianity is responsible for exercising a new moralising meaning in the mythical beast. The analogical interpretation of natural beings, characteristic of the Late Antiquity and the Middle Ages ${ }^{26}$, identified in the Siren symbols related to the temptation of the flesh, heresy and death. Two works of ample circulation in the MiddleAges attested to this moralisation. The Physiologus associated sailors seduced by the Sirens' song with 'those deceived men who delight in the charms of the world, in games and the pleasures of theatre ${ }^{27}$. Dispelled by various tragedies and melodies and asleep, these men become prey to their enemies" 28 . On the other hand, Etymologiae defined Sirens as "harlots who seduce sailors and cause shipwrecks. They said they had wings and claws because the sexual desire both flies and hurts ${ }^{29}$ ". By incorporating Homer's

\footnotetext{
${ }^{21}$ Faral, op. Cit., p. 441.

${ }^{22}$ Ibid., p. 460.

${ }^{23}$ Besides the bird and fish Siren, illustrated together or not, there could be identified Sirens in the form of a horse or bull-woman hybrid (Pérez Suescun, López, op. Cit, p. 60).

${ }^{24}$ Hassig, Debra, Medieval Bestiaries: Text, image, ideology, Cambridge University Press, Cambridge, 1995, p. 105.

${ }^{25}$ The Sirens figure as oneofthemost common themes in PortugueseRomanesque (see Costa, Joaquim Luís, Luxúria e iconografia na escultura românica portuguesa [Luxuryandiconography in PortugueseRomanesquesculpture], inMedievalista, $n^{\circ} 17$, 01/06/2015, https://journals.openedition.org/medievalista/1489).

${ }^{26}$ Pastoureau, Michael. Símbolo, in Dicionário temático do ocidente medieval, [Symbol, in ThematicDictionaryof Medieval Occident], EDUSC, Bauru, 2002, p. 497.

${ }^{27}$ Faral, op. Cit, p. 438.

${ }^{28}$ Curley, Michael J., Physiologus: a medieval book of nature lore, University of Chicago Press, Chicago, 1979, p. 23.

${ }^{29}$ Hassig, op. Cit., p 104.
} 
myth into Christian doctrine, the new narrative promoted Ulysses as a Christian hero by overcoming the temptation of sins and consolidating himself as an example to be followed ${ }^{30}$.

Consequently, the Siren's moralising connotation and its physical description as a bird-woman were reproduced in the main works on the natural world that circulated in the Middle Ages ${ }^{31}$. On the other hand, in art, the pisciform Siren's presence surpassed the avian Siren, despite the two forms coexisting. These two traditions (text and imagery), independent of one another and with different susceptibility to influences, were combined in the bestiaries, promoting a relationship between text and image where they do not always agree with each other.

\section{The bestiary's Siren}

Both the avian and pisciform physical styles of the Siren are normally found in the bestiary illustrations. As we deal with several manuscripts, a historian's first impulse would be to analyse each text in order to understand the choice of a specific form. Nevertheless, bestiaries are characterizedashaving a remarkable similarity to each other's verbatim. Indeed, the bestiaries analysed in this research have the same text for the Siren's chapter ${ }^{32}$.

This text consists of references to the followingtwo works: The Physiologus and the Etymologiae ${ }^{33}$. Regarding the Siren's physical form, both sources agree that itis a hybrid of a woman and a bird. According to the Physiologus, the Sirens have, from the head to the stomach, the figure of men, and wings and bird's feet on the lower part ${ }^{34}$; whereas, for the Etymologiaes, the Sirens were "part maidens, part birds, having wings and claws; the first Siren made music with the voice, the second with a flute, and the third with a lyre" ${ }^{35}$. Since these sources are dated respectively from the third and $6^{\text {th }}$ century, it is not surprising that the association with the bird Siren, inherited from ancient sources, is still preserved in them. Thus, inverbatim, bestiaries contribute to the Sirens' image only withelements associated with an avian characteristic, repeating them in all manuscripts.

Observe, for instance, the following images:

\footnotetext{
${ }^{30}$ Leclercq-Marx, op. Cit.

${ }^{31}$ Besides the Etymologiae and the Physiologus, there are other examples, such as De NaturaRerum and De Universo.

${ }^{32}$ That is not the case, for example, of the French bestiaries, excluded from this research because they have a different composition and function from the others (see McCulloch, op. Cit.,pp. 45-69).

33 Some manuscripts will only present the citation toPhysiologus, namely those from the second family (according to McCulloch's bestiary classification).

${ }^{34}$ Faral, op. Cit., p. 438.

${ }^{35}$ Ibid., p. 440.
} 


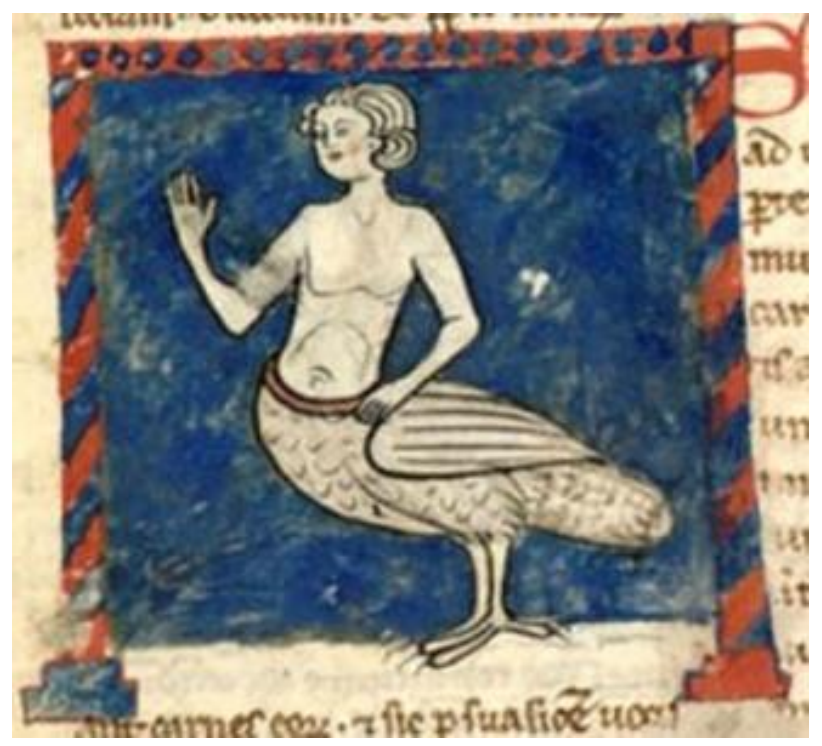

Fig.1 Lat. 6838B, Bibliothèque Nationale, f. 25v

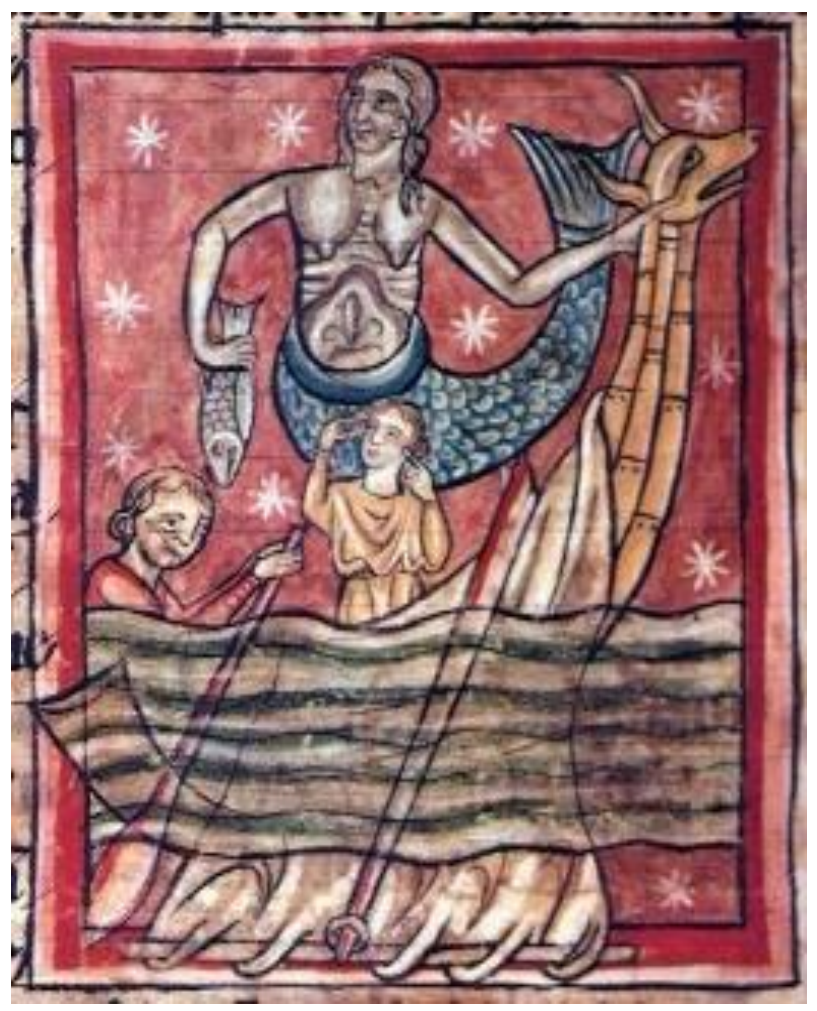

Fig. 2 Harley MS. 4751, British Library, f. 47v 


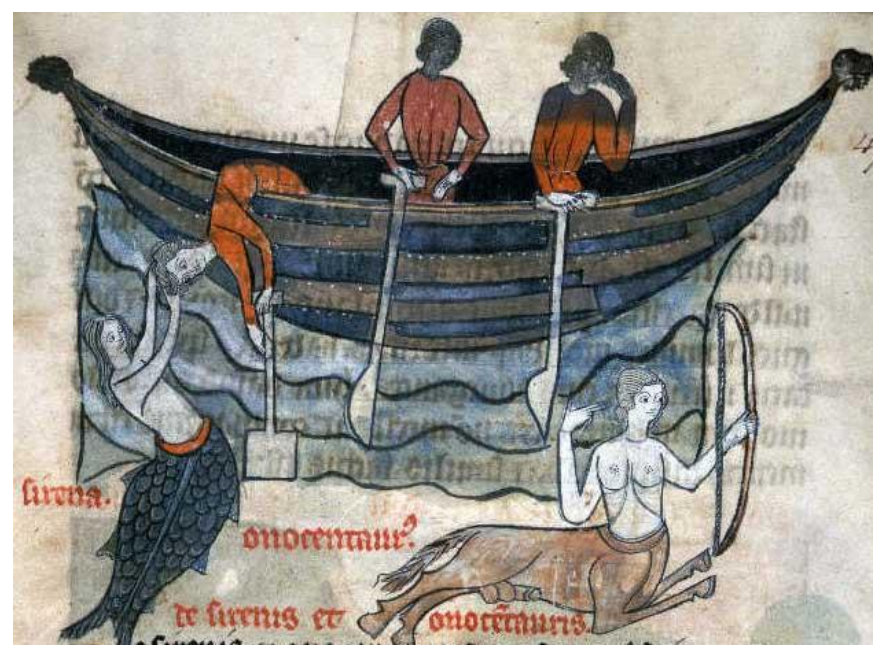

Fig.3 Sloane MS. 278, British Library, f. 47r

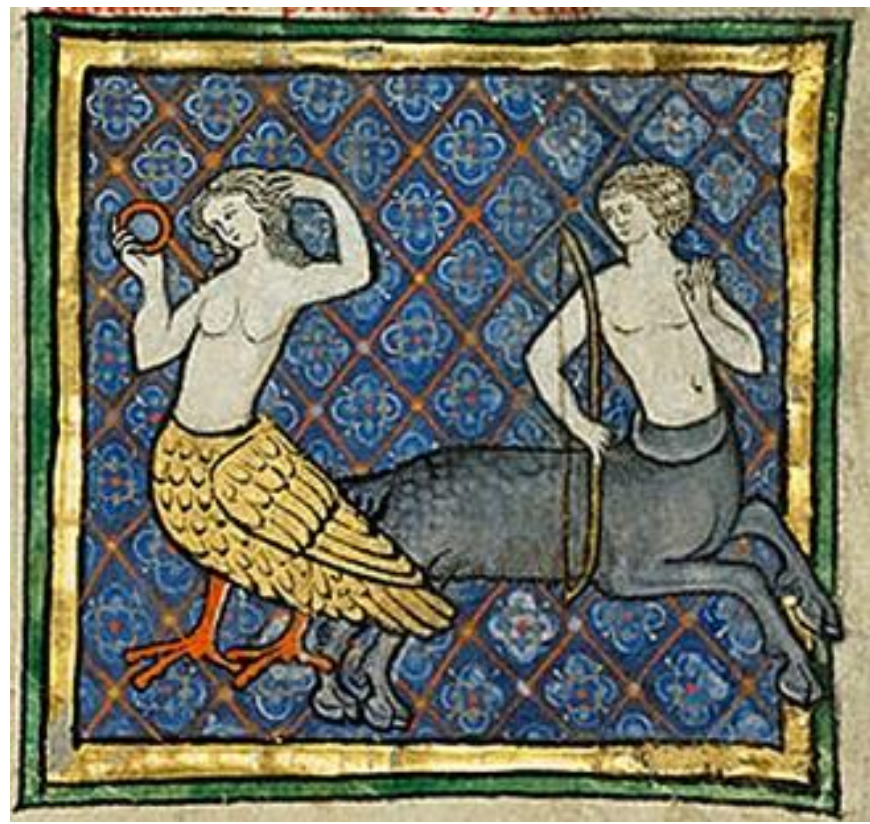

Fig.4 MS. Ludwig XV 3, Getty Museum, f. 78r

The selected examples illustrate situations and ways of the Siren's iconographical representations. Thus, in the first example (fig.1), the Siren appears represented with a female torso, with arms, breasts, and bottom of a bird, while in the second example (fig. 2), the bottom part is formed by a 
fishtail. In the following images (fig. 3 and fig. 4), the seductive beast appears next to the centaur. This occurrence is common in manuscripts where these mythical creatures share the chapter (however, there are no text changes). In these cases, Sirens can be either bird-woman orfish-woman. Interestingly, the Siren may also be accompanied by elements related to the morals attributed to them in the bestiary. For example, in the Harley 4751 bestiary (fig. 2), the Siren holds a fish, and in the Ludwig bestiary (fig. 4), in addition to a comb, the Siren has a mirror and looks at it while combing its hair. The comb and mirror are symbols related to vanity and temptation ${ }^{36}$.We believe that, in reality, the fish, is related to a more symbolic aspect, reproducing the seduction of Christians (usually symbolised by fish in Christendom), although it was pointed out as an indicator of the marine characteristic of the fish Siren ${ }^{37}$. Finally, Sirens could also be illustrated with boats and sailors (figs. 2 and 3).

Some researchers have mistakenly linked the bestiary bird Siren to the harpy ${ }^{38}$. They have disregarded that, although physically similar, harpies and Sirens are different beasts with distinct origins and symbology. Harpies are fierce creatures from Greek mythology, monsters that attack humansor Hades' servants. In Antiquity, they were also illustrated as a hybrid of awoman andabird, but with the difference that these, unlike Sirens, had no arms or human torso, only human head. In the Middle Ages, the iconographic representation of the harpy was even more differentiated, taking place in two ways: either it had a human head, the body of a bird and the tail of a snake or scorpion, also being illustrated with snakes that came out of its mouth ${ }^{39}$, or it had a lion torso with wings, human head and horse bottom ${ }^{40}$.In addition, the moralisation they acquired in medieval times was different from the Sirens. Harpies were evil beasts that represented greed, fraud and falsehood ${ }^{41}$. The unpleasant aspect was repeatedly present in the beast's images, unlike the Siren, who was always seductive and illustrated with soft forms ${ }^{42}$.

Whereas the representations of bird-woman hybrids in Romanesque art generated doubts for art historians as to which creature was represented ${ }^{43}$, this doubt is invalid in the bestiaries, as there is no chapter or textual mention of harpies. Given the symbolic and physical differences between the two

\footnotetext{
${ }^{36}$ Peinado, Laura Rodríguez, Las Sirenas, inRevista Digital de Iconografia Medieval, $\mathrm{n}^{\circ}$, 2009,pp. 51-63, p. 52.

${ }^{37}$ Hassig, op. Cit., p. 107.

${ }^{38}$ Pastoureau, Bestiaires du Moyen Age, p. 190.

39 Olivares Martínez, Diana, Lasarpías, inRevista Digital de Iconografia Medieval, $\mathrm{n}^{\circ} 11$, 2014, pp. 1-12, p. 2.

${ }^{40}$ Leclercq-Marx, op. Cit.

${ }^{41}$ Olivares Martínez, op. Cit., p. 5

${ }^{42}$ Ibidem.

${ }^{43}$ Leclercq-Marx points out that many bird Sirens were mistakenly identified as harpies, who had a much smaller representation in the Romanesque (Leclercq-Marx, op.Cit.).
} 
beasts in the MiddleAges, the lack of quotation about harpies and the fact that the text accompanying the illustrations identifies the hybrid bird-woman as a Siren, one can discard this association. Thus, there is no doubt that the bird Siren is illustrated as it follows the description given by the text.

If the avian Siren's illuminator follows what the text says, the same does not happen with the pisciform Siren's illuminator. The divergence of what is textually described and what is actuallyillustrated draws our attention, but it does not surprise us in any way. Indeed, it is not uncommon to find images in bestiaries that do not accurately represent the information provided verbatim or do contain elements unfound in the text $t^{44}$. The relation that the image has with the text will depend not only on the analysed manuscript, but also on the analysed beast ${ }^{45}$. With this, we can affirm that the illustrationis not subordinated to the text. In fact, contrary to historians who first studied bestiaries $^{46}$, images do not behave just as a complement for a better comprehension of the text. As part of an independent tradition, the illustration is susceptible to influences capable of modifying it. Therefore, only the analysis of the text alone cannot explain the image $e^{47}$.

In a recent article, Ilya Dines develops McCulloch's point about the differences between illustration and text in bestiaries ${ }^{48}$. The twoauthors state that during the manuscript's production, the illuminator's interpretation of the text would essentially define the elements and forms to be illustrated ${ }^{49}$. In the case of Sirens, each illuminator's understanding may have been responsible for the illustration of some features that are indirectly present, although they are not mentioned directly in the text,such as the comb and mirror - attributes of seduction. However, concerning the divergence regarding the Siren's physique in illustrations, where she is a fish-woman, the argument finds no basis since the text does not reference the Siren as a marine creature. On the contrary, it specifies the Siren's physical composition as a bird-woman hybrid. Thus, there is no room for interpreting the Siren as a fish-woman based on the text alone ${ }^{50}$.

\footnotetext{
${ }^{44}$ Dines, Iya, Producing the Bestiary: from text to image, in Medievalista, $\mathrm{n}^{\circ} 29,2011$, pp. 93 116.

${ }^{45}$ See Garcia, Muriel Araujo Lime, As imagens em bestiários ingleses dos séculos XII e XIII, Dissertação de Mestrado, Universidade de São Paulo, 2015 [The images in EnglishBestiariesoftheXIIandXIIIcenturies, Master'sdissertation, Universityof São Paulo, 2015].

${ }^{46}$ SeeBaxter, Ron,Bestiaries and their users in the Middle Ages, Sutton Publishing, Stroud, 1998, pp. 1-28.

${ }^{47}$ Garcia, op. Cit.,p. 16.

${ }^{48}$ Dines, Ilya, Producing the Bestiary: FromText to Image, inMedievalista, $\mathrm{n}^{\mathrm{o}} 29,2021$, https://journals.openedition.org/medievalista/3842, pp. 91-116.

${ }^{49}$ Ibid., p. 95; McCulloch, op. Cit., p. 71.

${ }^{50}$ Another element that corroborates with the idea that the illuminator would be susceptible to external influences is that in the Harley 4751 bestiary (fig. 2), the sailor raises his fingers to his ears to cover them avoid listening to the Siren's song. This reference is not present in the
} 


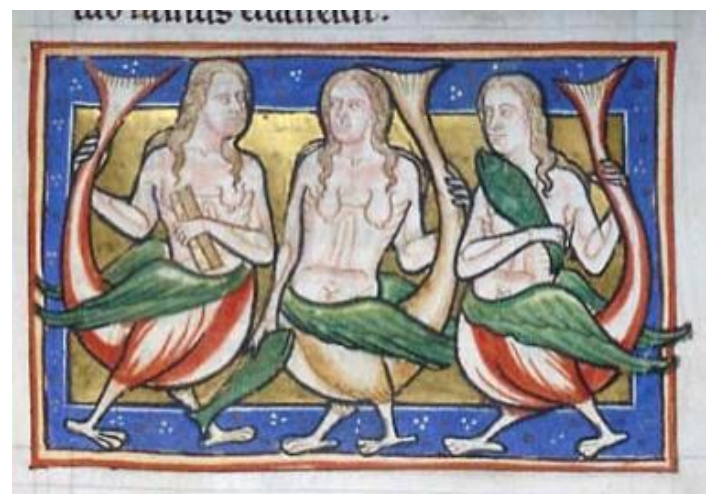

Fig.5. MS. 81, Morgan Library, f. 17r

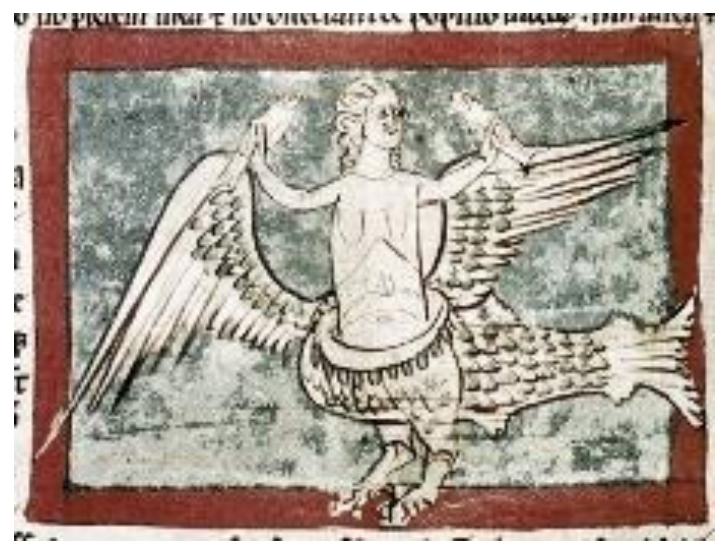

Fig.6. MS.Douce 88, Bodleian Library, f. 21v

Accordingly, if the text does not give the marine feature a reference to the illuminator, where does it originate?

The illuminator's reference probably came from the collective imagery that would already have consolidated the Siren's conception as a fish-woman instead of a bird-woman. This transformation had been developing since Antiquity, when the first interpretations of the Siren as a fish hybrid were made, and was at its peak in the Middle Ages, considering the majority of pisciform representations of the Siren in architectural art (especially capitals and porticoes $)^{51}$. Consequently, the form that Sirens could be figured (avian or pisciform) would depend on the level of susceptibility of each bestiary's illuminator to external connections.

bestiary's text, but it is part of the Odyssey tale, which in turn is widely disseminated among the medieval elite (Hassig, op. Cit., p. 107).

${ }^{51}$ Leclercq-Marx, op. Cit. 
In a mid-term situation, where the illuminator wanted to respect textual information and meet the influence he received, a unique type of Siren is originated, with a physical form that combines characteristics of human, bird and fish altogether.

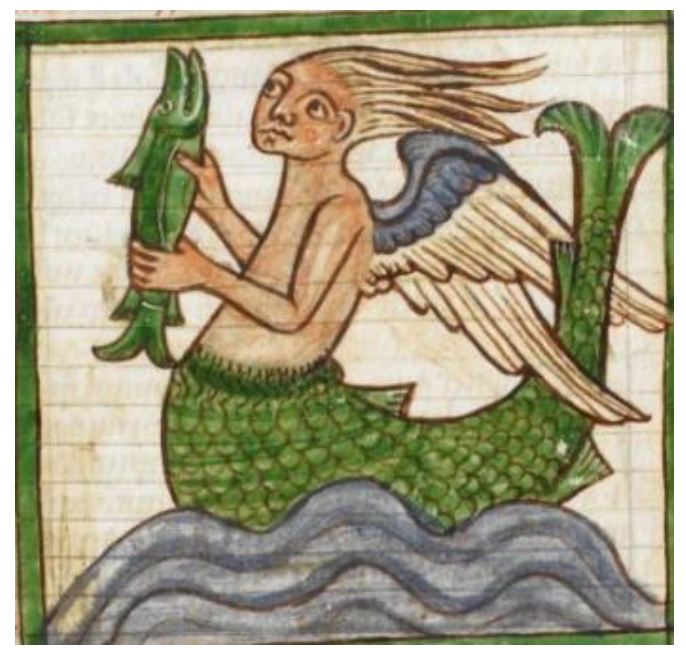

Fig.7. Harley 3244, British Library, f. 55r

The Sirens illustrated above share the characteristics of hybrids of women, fish and birds. They have a female head and torso, with arms holding a comb (fig.5) or a fish (figs. 5, 6 and 7). The lower part is elongated with a fishtail, and they have wings that rise from the waist's height (figs. 5 and 6) or on the back (fig. 7). In the first two images (fig. 5 and 6), the Sirens also have bird feet.

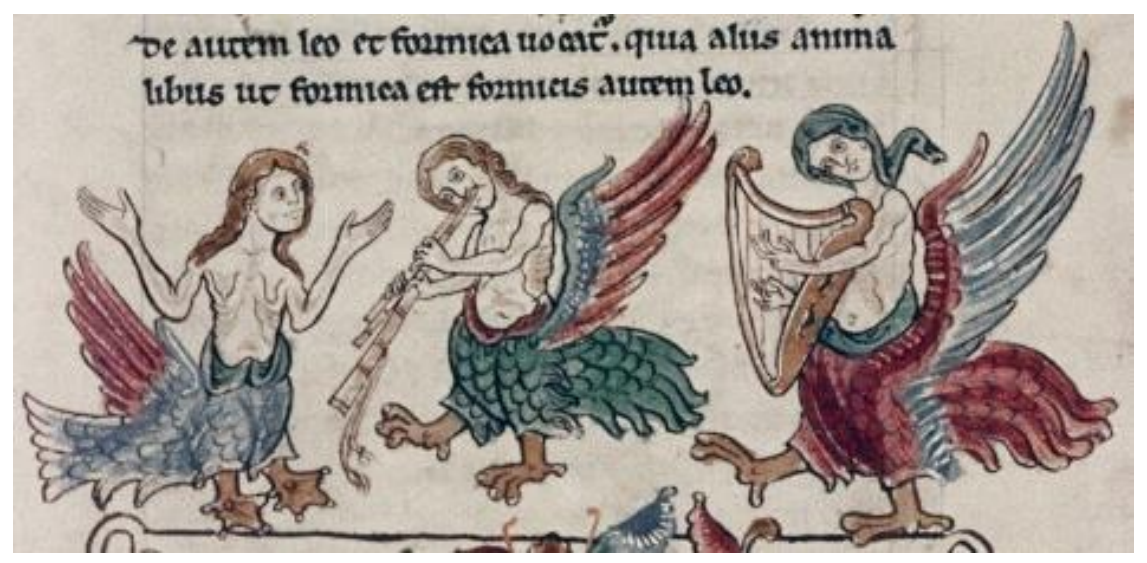

Fig.8. MS.Bodley 602, Bodleian Library, f. 10r 
The illuminator who illustrated the three Sirens above made particular reference to the Sirens described by the Etymologiae, as follows: the firstSiren singing, the second oneplaying the flute and the third playing the lyre (fig. 8). While the two Sirens on the rightare equally pictured with bird's features (feathers, wings and claws), the fact that the one on the leftis different draws our attention. Except for the wings, it has distinct features compared to the other Sirens, with a tail and a more similar aspect to that of a fish. In addition, it has webbed feet, another allusion to its marine essence. As Hassig points out, this characteristic could demonstrate the illuminator's interpretation that the Siren would be a sea bird, similar to ducks and swans $^{52}$. This illustration of the Siren as close to a marine bird reveals the illuminator's effort to link both text and imagery influence in the same image.

\section{Conclusion}

The three hybrids (fish-woman, bird-woman and fish-bird-woman) illustrate the same mythical creature and therefore have equivalent symbolism, as is confirmed by the bestiaries' text. It is not, like some attest, confusion between different beasts, but various forms of representation of the same creature. The Siren's fish characteristic in specific images exemplifies the external influences during a bestiary's production (in this case, the Siren was conceived as a fish-woman in the medieval imagery). Simultaneously, the Siren's occurring as a fish-bird-woman demonstrates that both textual and imagery traditions had equal importance for the illuminators. These results corroborate the interpretation that each bestiary has its particularities and that the illustrations are not only decorative and subordinated to the text, but also imaginative and creative.

\section{List of Illustrations:}

Fig. 1.Lat. 6838B, Paris, Bibliothèque Nationale, f. 25v.

Fig. 2.Harley MS. 4751, London, British Library, f. 47v.

Fig. 3. Sloane MS. 278, London, British Library, f. 47r.

Fig. 4.MS. Ludwig XV 3, Malibu, Getty Museum, f. 78r.

Fig. 5.MS. 81, New York, Morgan Library, f. 17r.

Fig. 6. MS.Douce 88, Oxford, Bodleian Library, f. 21v.

Fig. 7.Harley 3244, London, British Library, f. 55r.

Fig. 8.MS. Bodley 602, Oxford, Bodleian Library, f. 10r.

${ }^{52}$ Hassig,op. Cit., p. 108. 


\section{Bibliography:}

Baxter, Ron, Bestiaries and their users in the Middle Ages, Sutton Publishing, Stroud, 1998.

Costa, Joaquim Luís, Luxúria e iconografia na escultura românica portuguêsa [Luxuryandiconography in PortugueseRomanesquesculpture], inMedievalista, $\mathrm{n}^{\circ}$ 17, 2015, http://journals.openedition.org/medievalista/1489.

Curley, Michael J., Physiologus: a medieval book of nature lore, University of Chicago Press, Chicago, 1979.

Dines, Ilya, Producing the Bestiary: From Text to Image, inMedievalista, $\mathrm{n}^{\mathbf{0}} 29$, 2021, https://journals.openedition.org/medievalista/3842, pp. 91-116.

Faral, Edmond, La queue de poisson des sirènes, in Romania, no 296, 1953, pp. 433-506.

Garcia, Muriel Araujo Lima, As imagens em bestiários ingleses dos séculos XII e XIII, Dissertação de Mestrado, Universidade de São Paulo, 2015 [The images in EnglishBestiariesoftheXIIandXIIIcenturies, Master'sdissertation, UniversityofSão Paulo, 2015].

Hassig, Debra, Medieval Bestiaires: Text, image, ideology, Cambridge University Press, Cambridge, 1995.

Holford-Strevens, Leofranc, Sirens in Antiquity and the Middle Ages, inMusic of the Sirens, Indiana University Press, Bloomington, 2006, pp. 16-51.

Leclercq-Marx, Jacqueline, La Sirène dans la pensée et dans l'art de l'Antiquité et du Moyen Âge, 02/10/2014, http://www.koregos.org/fr/jacqueline-leclercq-marx-lasirene-dans-la-pensee-et-dans-1-art-de-l-antiquite-et-du-moyenage/4389/\#chapitre_4389.

McCulloch, Florence, Mediaeval latin and french bestiaries, University of North Carolina Press, Chapel Hill, 1962.

OlivarezMartínez,Diana, LasArpías, inRevista Digital de Iconografia Medieval, $\mathrm{n}^{\circ}$ 11, 2014, https://www.ucm.es/bdiconografiamedieval/numero-11.

Pastoureau, Michel, Bestiaires du Moyen Âge, Seuil, Paris, 2011.

Pastoureau, Michel, Símbolo, inDicionário temático do ocidente medieval [Symbol, inThematicDictionaryof Medieval Occident], EDUSC, Bauru, 2002, pp. 495-510.

Peinado, Laura Rodríguez, Las Sirenas, inRevista Digital de Iconografia Medieval, no 1, 2009, https://www.ucm.es/bdiconografiamedieval/numero-1, pp. 51-63.

Pérez Suescun, Fernando; López, Maria Victoria Rodríguez, Las sirenas medievales: aproximación literária e iconográfica, inAnales de Historia del Arte, $\mathrm{n}^{\circ}$ 7, ServicioPublicacionesUCM, Madrid, 1997, pp. 55-66.

Rodríguez López, Maria Isabel, La música de las sirenas, inCuadernos de Arte e Iconografia, $\mathrm{n}^{\circ}$ 32,FundaciónUniversitariaEspañola, Madrid, 2007, 333-356.

Touchefeu-Meynier, Odette, De quand date la Sirène-poisson ? in Bulletin de l'Association Guillaume Budé : Lettres d'humanité, no 21, 1962, pp. 452-459. 